\title{
Prevalence of gastrointestinal parasites in sheep and goats in and around Mathura, I ndia
}

\author{
V. Singh ${ }^{1}$, P. Varshney ${ }^{2}$, S. K. Dash ${ }^{2}$ and H. P. Lal ${ }^{1}$
}

1 Department of Medicine, College of Veterinary Science, Pt. Deen Dayal Upadhyaya University of Veterinary and Animal Sciences (DUVASU), Mathura, India; 2 Department of Microbiology and I mmunology College of Veterinary Science, Pt. Deen Dayal Upadhyaya University of Veterinary and Animal Sciences (DUVASU), Mathura, India.

Corresponding author: Sandeep Kumar Dash, email: sandeepkumar.dash@gmail.com

Received: 08-09-2012, Accepted: 29-09-2012, Published online: 06-02-2013

\section{How to cite this article:}

Singh V, Varshney P, Dash SK and Lal HP (2013) Prevalence of gastrointestinal parasites in sheep and goats in and around Mathura, India, Vet. World 6(5):260-262, doi: 10.5455/vetworld.2013.260-262

\begin{abstract}
Aim: To study the prevalence of gastrointestinal parasites in sheep and goats of Mathura region.

Materials and Methods: A total of 240 faecal samples collected from three different farms were examined by direct smear, Willi's floatation and sedimentation techniques. Quantitative examination was done by McMaster's technique.
\end{abstract}

Results: Out of 240 samples processed 165 samples were found positive for gastrointestinal parasites. The overall prevalence was $68.75 \%$. The most common gastrointestinal parasites were Haemonchus, Moniezia and coccidia.

Conclusions: The results of the present study suggest that Haemonchus is the main gastrointestinal parasite of sheep and goats in Mathura region. Necessary steps should be taken in timely manner to improve the productivity from these animals.

Keywords: gastrointestinal parasites, Haemonchus, sheep and goats, Mathura

\section{Introduction}

Sheep and goats are the earliest ruminants to be domesticated. They can withstand a period of drought better than any other livestock and they can use those pastures, which cannot be used by other livestock. Goats can survive under limited fodder need and they are capable to withstand water scarcity [1]. Sheep and goats are important source of animal protein. Gastrointestinal parasitic infections in sheep and goats are of much economic importance because small ruminants' rearing has been a major source of income especially to the marginal farmers of the country [2]. Recurring losses in productivity due to widely prevalent parasitic infection is an important and common problem for small ruminant production in most parts of the world [3].

Commonly occurring gastrointestinal parasitic diseases in goats and sheep are Haemonchosis, Ostertagiasis, Strongyloidosis, Oesophagostomiasis, Bunostomiasis and Trichostrongylosis. Among the nematodes, Haemonchus contortus is the most important. The degree of infestation may be sub clinical or clinical depending on level of parasitic load. Sub clinical infections remain dominant and as such are not recognized by the clinicians and owners. Thus the sub clinical and clinical infection should be tackled timely for better economic return.

\section{Materials and Methods}

In the present study faecal samples of 240 sheep and goats from three locations around Mathura were examined to know the prevalence of gastrointestinal parasites in these animals during the study period 2008-09 (Table-1). The faecal samples were collected directly from the rectum of each animal. Gross examination was done for colour, consistency and for presence of any adult worms. The faecal samples were processed and screened by direct smear method, Willi's floatation and sedimentation techniques. The ova of parasites were identified from their morphological features [4]. Quantitative examination of faeces was conducted to know the intensity of parasitic infestation (EPG) by McMaster's technique. Animals detected positive by faecal examination were classified in to sub clinical $(\mathrm{EPG}<1600)$ and clinical $(\mathrm{EPG}>1600)$ [5] (Table-2). Further classification was made by type of parasites eggs present and as pure and mixed infections (Table-3).

\section{Results}

In the Veterinary college farm, 30 out of 40 goats (75\%) were found to be positive for gastrointestinal parasites. In Aurangabad farm, out of 150 faecal samples of goats 101 samples $(67.33 \%)$ were found positive whereas at the Madhurikund farm, 34 out of 50 sheep $(68 \%)$ were found to be positive. By EPG values for parasitic infected goat, the prevalence of subclinical infection $(<1600)$ at Veterinary College, was $43.34 \%$, while the clinical infection was $56.66 \%$ (Table-4). The prevalence of subclinical infection at Aurangabad goat farm was $39.65 \%$ in Barbari goats and $41.87 \%$ in Jamunapari goats. While the clinical infection (>1600) was $60.34 \%$ in Barbari and $58.14 \%$ in Jamunapari goats. At Madhurikund farm the subclinical infection 
Table- 1. Animal population studied

\begin{tabular}{llc}
\hline Species & Place & Number of Animals \\
\hline Goats & Goat farm, Veterinary college, Mathura & 40 \\
& Goat farm, Aurangabad, Mathura & 150 \\
Sheep & Sheep farm, Madhurikund, Mathura & 50 \\
Total & & $\mathbf{2 4 0}$ \\
\hline
\end{tabular}

Table-2. Range of EPG values in sub clinical and clinical gastrointestinal parasites in goats and sheep at different places of Mathura district.

\begin{tabular}{|c|c|c|c|c|c|}
\hline \multirow[t]{2}{*}{ Place } & \multirow[t]{2}{*}{ Animal } & \multicolumn{2}{|c|}{ Range of EPG Value } & \multicolumn{2}{|c|}{ Average EPG Value } \\
\hline & & Sub clinical & Clinical & Sub clinical & Clinical \\
\hline Goat Farm Veterinary College, Mathura & Barbari (40) & $380-1410$ & $1680-3100$ & 895 & 2390 \\
\hline \multirow[t]{2}{*}{ Goat Farm Aurangabad, Mathura } & Barbari (80) & $550-1560$ & $1800-3600$ & 1055 & 2700 \\
\hline & Jamunapari (70) & $540-1520$ & $1750-3540$ & 1030 & 2645 \\
\hline Sheep Farm Madhurikund, Mathura & Sheep (50) & $440-1480$ & $1640-3300$ & 960 & 2470 \\
\hline
\end{tabular}

Table-3. Prevalence of gastrointestinal parasites in goats and sheep at different places of Mathura district

\begin{tabular}{|c|c|c|c|c|c|c|c|c|c|}
\hline \multirow[t]{2}{*}{ Place } & \multirow[t]{2}{*}{ Animal } & \multicolumn{3}{|c|}{ Pure infection } & \multicolumn{4}{|c|}{ Mixed infection } & \multirow[t]{2}{*}{ Total } \\
\hline & & Mo & Bur & Coc & Bur+Coc & Bur+Mo & $\mathrm{Mo}+\mathrm{Coc}$ & Bur+Mo+Coc & \\
\hline Goat Farm Veterinary College, Mathura & Barbari (40) & 0 & 16 & 7 & 4 & 3 & 0 & 0 & $30(75 \%)$ \\
\hline \multirow[t]{2}{*}{ Goat Farm Aurangabad, Mathura } & Barbari (80) & 6 & 21 & 14 & 7 & 5 & 3 & 2 & $58(73.5 \%)$ \\
\hline & Jamunapari (70) & 5 & 15 & 11 & 4 & 4 & 2 & 2 & $43(61.43 \%)$ \\
\hline Sheep Farm Madhurikund, Mathura & Sheep (50) & 0 & 16 & 9 & 9 & 0 & 0 & 0 & $34(68 \%)$ \\
\hline
\end{tabular}

Bur $=$ bursate, Coc $=$ Coccidia, Mo $=$ Moniezia

Table-4. Prevalence of clinical and sub clinical gastrointestinal parasites in goats and sheep at different places of Mathura district.

\begin{tabular}{|c|c|c|c|c|}
\hline \multirow[t]{2}{*}{ Place } & \multirow[t]{2}{*}{ Animal } & \multicolumn{2}{|c|}{ Prevalence } & \multirow[t]{2}{*}{ Over all Prevalence } \\
\hline & & Subclinical & Clinical & \\
\hline \multirow{3}{*}{$\begin{array}{l}\text { Goat Farm Veterinary College, Mathura } \\
\text { Goat Farm Aurangabad, Mathura }\end{array}$} & Barbari (40) & $13(43.34 \%)$ & $17(56.66 \%)$ & $30(75 \%)$ \\
\hline & Barbari (80) & $23(39.65 \%)$ & $35(60.34 \%)$ & $58(73.5 \%)$ \\
\hline & Jamunapari (70) & $18(41.87 \%)$ & $25(58.14 \%)$ & $43(61.43 \%)$ \\
\hline Sheep Farm Madhurikund, Mathura & Sheep (50) & $14(41.17 \%)$ & $20(58.82 \%)$ & $34(68 \%)$ \\
\hline
\end{tabular}

was $41.17 \%$, while the clinical infection in sheep was $58.82 \%$ (Table- 4$)$.

\section{Discussion}

Infection of gastrointestinal parasites was recorded (75\%), the highest in Veterinary college farm. This finding is also in close agreement to early work carried out by Sharma (1998) who reported 29.6 to $100 \%$ infection spread over the entire year at college campus [6]. However, higher rates of infection throughout the year in goats were reported by previous workers $[7,8]$. Various studies have been conducted on prevalence of gastrointestinal parasites in sheep and goats in this country and abroad [2,7-12]. This variation in prevalence of parasitic infestation depends upon difference in agro climatic condition and availability of susceptible host [13]. Out of 30 parasitic infected goats in Veterinary college farm, 16(53.34\%) goats harboured bursate worms (Haemonchus), 7(23.34\%) harboured coccidian worms and $7(23.34 \%)$ animals had mixed parasitic infection.

At Aurangabad goat farm, breed wise infection was recorded. Out of 80 Barbari goats, 58(75.5\%) goats were found to be positive for parasitic infection, out of which 21 (36.2\%) goats harboured bursate worms (Haemonchus), 14 (24.13\%) coccidian, 6 (10.34\%) Moniezia and 17 goats contain infections of bursate worm, composed of Strongyles spp, Bunostomum spp., Oesophagostomum spp. and Trichostrongylus spp. (Table-3). Out of 70 Jamunapari goats in Aurangabad farm, 43(61.43\%) goats were found to be positive for G.I.T parasites infection, out of which $15(34.88 \%)$ goats harboured bursate worm (Haemonchus), 11(25.58\%) coccidian worms, 5(11.62\%) Moniezia and 12 harboured infections of bursate worm composed of Strongyles spp, Bunostomum spp., Oesophagostomum spp. and Trichostrongylus spp. (Table-3). Breed variation have been reported earlier [14].The data revealed highest percentage of bursate worm infection in both Jamunapari and Barbari goats, Further the overall prevalence of parasitism was slightly lower in Jamunapari (61.43\%) than Barbari goats (73.5\%) (Table-3). Occurrence of Moniezia infection along with bursate worm is not uncommon. Other researchers also reported Moniezia infection along with bursate worm infections in goats and sheep in India and abroad [15,16,17].

At the unit of Madhurikund farm, out of 50 sheep $34(68 \%)$ were found to be positive for gastrointestinal parasitic infection. Out of 34 infected sheep, 16(47\%) harboured bursate worms (Haemonchus), 9(26.47\%) harboured coccidian worms and $9(26.47 \%)$ had mixed infections (Table-3). In this study, high prevalence of bursate worm infection in both sheep and goats has 
been observed which has also been reported earlier $[18,19,20]$. The overall bursate worm infections in this study as both pure and mixed infections were $35.71 \%$ in Jamunapari goats and $48.34 \%$ in Barbari breeds of goats. Variation may be due to change in management practices of different flocks and opportunity of grazing in the infected field. Sharma (1998) also reported about 63.3\% infections with Haemonchus spp. at the same farm [6]. 27.5\% faecal samples of Veterinary college and $36 \%$ of sheep at Madhurikund farm and $26.66 \%$ of Aurangabad farm were found to be positive for coccidial oocyst. However previous researchers have reported $32-41 \%$ prevalence of coccidia in sheep of Mathura region [11].

\section{Conclusions}

The results of the present study suggest that Haemonchus is the main gastrointestinal parasite of sheep and goats in Mathura region. Necessary steps should be taken in timely manner to improve the productivity from these animals.

\section{Authors' contribution}

All the authors contributed equally for this study. All author read and approved the final manuscript.

\section{Acknowledgements}

Authors are thankful to the University authorities for providing necessary facilities to carry out this research work.

\section{Competing interests}

Authors declare that they have no competing interest.

\section{References}

1. Upadhyay, B. A. (2003) Goat breeding strategy with reference to commercial goat production. Deptt. of Animal Science \& Dairy Science, Mahatma Phule Krishi Vidhyapeeth, Rahuri, Maharastra. State level workshop on recent advance in goat rearing, 29-30 Dec.

2. Pathak, A. K. and Pal, S. (2008) Seasonal prevalence of gastrointestinal parasites in goats from Durg district of Chhattisgarh. Vet. World. 5: 136-137.

3. Gall, C. (1981) Goat production, Academic press, London/New York.

4. Soulsby, E. J. L. (1982) Helminths, arthropods and protozoa of domesticated animals. 6th Ed. CLBS and Bailliere Tindal.pp. 788.

5. Arora, N., Kumar, A., and Sharma, S. D. (2003) Prevalence of Haemonchus infection on goats under semi-intensive system. Indian Journal of Animal Sciences, 73 (11): 12001201.

6. Sharma, D. K. (1998) Studies on interaction between Trypanosoma evansi and Haemonchus contortus infections in goats with special reference to clinico-pathologic changes (Ph.D. Thesis) submitted to Pandit Deen Dayal Upadhyaya Veterinary and Animal Sciences University, Mathura.

7. Pandey, V. S., Ndao, M. and Kumar, V. (1994) Seasonal prevalence of gastrointestinal nematodes in communal land goats from high yield of Zimbabwe. Vet. Parasitol. 51: 241248.

8. Saha, S. B., Pramanik, S. and Mukherjee, G. S. (1996) Prevalence of gastrointestinal nematodes of goats in West Bengal. Indian Journal of Animals Science, 11 (1): 51-52.

9. Singh, A., Hazarika, G. C., Pukhan, A., Hussain, P. (2010) Seasonal Incidence of Caprine Gastrointestinal Nematodosis. Vet. World 3(7): 321-322.

10. Sutar, A. U., Kengar, S. B., Patil, S. S., Khan, M. R. (2010) Prevalence of gastrointestinal Parasites in Goats of Ahmednagar district of Maharashtra. Vet. World 3(10): 456457.

11. Om, H., Kumar, S., Singh, P. (2010) Prevalence of Coccidia in Mathura Region of Uttarpradesh. Vet. World. 3(11): 503505.

12. Pant, K., Rajput, M. K. S., Kumar, J., Sahu, S., Rajkumari, V., Gangwar, P. (2009). Prevalence of helminthes in small ruminants in Tarai region of Uttarakhand. Vet. World. 2 (7): 265-266.

13. Radostits, O. M., Gay, G. C., Blood, D. C., Hinchkiliff, K. W. (2000) Veterinary medicine 9th ed. EIBS and Bailliere Tindal.

14. Yadav, S. C. and Senegar, O. P. S. (1982) Breed variations in gastrointestinal parasitism of Indian goats. Proc. III International Conf. Goat Prod. Dis., Turson Arizona, p.342.

15. Leimbacher, F. and Liabeuf, J. M. (1984) Information on the nature, economic importance and epizootiology of the principal diseases of small ruminants in French West Indies. In Les Maladies da la chevre Colloque International, Niort, France, Institute National de la Recherche Agronomique (INRA), pp. 731-742.

16. Sani, R. A., Awang, I. P. R., Sheikh-Omar, A. R. (1985) Incidence and factors effecting endoparasitism in Serdang, West Malaysia, Kajian Veterinar., 17: 127-131.

17. Katoch, R., Mittra, S., Agnihotri, R. K. and Sharma, A. K. (1998) Strongylosis in sheep and goats at high altitude: a sporadic occurrence. Indian Vet. J., 75 (4): 326-362.

18. Contreras, J. A., Lopez, W. and Sanchez, J. (1976) Haemonchus infection in goats. Revista Veterinaria Venezolona, 40: 91-97.

19. Jurasek, V. (1986) Results of the laboratory examinations of parasitoses in animals of Mozambique goats. Folia Veterinaria, 30: 93-97.

20. Katoch, R., Chauhan, P. P. S. and Johri, D. K. (2000) Seasonal incidence of gastrointestinal nematodes in goats of Mathura region. Indian Vet. J. 77: 259-260. 